\title{
Influence of high-dose gamma radiation and particle size on antioxidant properties of Maize (Zea mays L.) flour
}

\author{
Haq Nawaz,"*, Muhammad Aslam Shad', Tanzila Rehman², Ayesha Ramzan² \\ ${ }^{1}$ Department of Biochemistry, Bahauddin Zakariya University, Multan, Pakistan, ${ }^{2}$ Institute of Chemical Sciences, Bahauddin \\ Zakariya University, Multan, Pakistan
}

\begin{abstract}
Influence of high-dose gamma radiation and particle size on antioxidant properties of maize (Zea mays L.) flour was studied using response surface methodology. A central composite design based on three levels of each of particle size, in terms of mesh number (40,60 and 80 meshes), and gamma radiation dose $(25,50$ and $75 \mathrm{kGy})$ was constructed. A statistically significant dose-dependent decrease $(p<0.05)$ in antioxidant properties of gamma irradiated flour was observed. However, an increase in the mesh number (decrease in particle size of flour) resulted in an increase in antioxidant properties. The optimum level of radiation dose to achieve maximum value of responses was found to be $50 \mathrm{kGy}$ for Trolox equivalent total antioxidant activity (TETAOA), $25 \mathrm{kGy}$ for iron chelating ability (ICA), $25 \mathrm{kGy}$ for reducing power (RP) and $75 \mathrm{kGy}$ for linoleic acid reduction capacity (LARC). However, the optimum level of mesh number to achieve desired levels of TETAOA, ICA, RP and LARC was found to be 80 meshes.
\end{abstract}

Uniterms: Maize flour/antioxidant properties. Maize flour/gamma irradiation/effects. Central composite design. Maize flour/particle size. Response surface methodology. Zea mays L.

\section{INTRODUCTION}

Antioxidants are a unique class of substances that are able to protect the biomolecules from oxidative damage caused by endogenous free radicals such as superoxide and hydroxyl radicals produced during various metabolic processes (Nimse, Pal, 2015; Lobo et al., 2010; Sisein, 2014). These free radicals may lead to protein denaturation, lipid per-oxidation, DNA lesions and finally diseased conditions if not captured effectively (Kabel, 2014; Valko et al., 2007). The antioxidants perform their action by trapping the free radicals, reducing the metal ions and preventing the initiation of free radical chain, hydrogen abstraction and peroxide decomposition (Nimse, $\mathrm{Pal}, 2015)$. A large number of natural compounds such as ascorbic acid, tocopherols, phenolic acids, flavonoids, anthocyanins, proanthocyanidins and other phytochemical compounds present in food materials have been reported to possess antioxidant properties due to the presence of hydrogen donating groups in their chemical structures (Goufo, Trindade, 2014; Shahidi, 2000). Foods rich in

\footnotetext{
*Correspondence: H. Nawaz. Department of Biochemistry. Bahauddin Za-
} kariya University, 60800 - Multan, Pakistan. E-mail: haqnawaz@bzu.edu.pk antioxidant compounds have been proved to be effective in decreasing the risk of cardiovascular mortality, destruction of cancer cells and preventing the oxidative lung damage (Miranda-Vilela et al., 2011; Khan et al., 2014).

The processing and preservation techniques significantly influence the nutritional and antioxidant properties of food materials. Gamma-irradiation is an extensively used method in industries for the sterilization of food materials and pharmaceutical products. It is also being used in food science technology to improve the nutritional and functional quality of various food materials (Abdelwhab, Nour, Fageer, 2009; Hassan et al., 2009; Gani et al., 2013). Studies have also shown that gamma irradiations significantly affect the antioxidant composition of plant and other food materials (Kortei et al., 2014; Hussein et al., 2011; Harrison, Were, 2007).

Maize, botanically known as Zea mays L., is the third most important cereal crop after wheat and rice in Pakistan. It is widely used as a source of starch, protein, vitamins and minerals in various food supplementations all over the world. It possesses great medicinal importance due to the presence of considerable amounts of naturally occurring antioxidant compounds including B-carotene, tocopherols, phenolic acids, flavonoids and anthocyanins (Mboya et al., 
2011; Nawaz, Shad, Batool, 2013). Previously, a few data have been reported regarding the gamma radiation induced variations in starch structure and nutritional quality of maize grains (Roushdi et al., 1981; Roushdi et al., 1983). However, no investigations have been reported on the effect of particle size and gamma irradiation on the antioxidant profile of maize flour. Therefore, the present study was designed to optimize the effect of particle size and gamma radiations on phytochemical composition and antioxidant activity of maize flour of different particle sizes using response surface methodology. The data would provide useful information regarding the processing and utilization of maize flour in pharmaceutical and food formulations.

\section{MATERIAL AND METHODS}

The maize grains were collected from Maize and Millet Research Institute (MMRI), Yousafwala, Sahiwal, Pakistan. The mature grains were separated manually, dried in air under shade to remove moisture, and ground to fine flour. The grinding was performed discontinuously using a low speed (1000 rpm) electric grinder in order to maintain the temperature at $35 \pm 5^{\circ} \mathrm{C}$. The flour was packed in airtight glass bottles and stored in dark at standard laboratory conditions until further processing.

\section{Experimental Design}

The cumulative effect of particle size and gamma radiations on antioxidant activity of maize flour of different particle sizes was investigated using response surface methodology (RSM). A bi-factorial facecentered central composite design (CCD) was employed to optimize the effect of two independent variables on antioxidant properties of maize flour. The selected levels of input variables are as follows:

$X_{l}$ : Particle size of flour in terms of sieve mesh number. Three levels of particle size in terms of sieve mesh number were selected as 40,60 and 80 meshes.

$X_{2}$ : Radiation dose

Three levels of radiation dose were selected as 25 , 50 and $75 \mathrm{kGy}$.

The codes for the selected levels of the two input variables were calculated using following generalized equations:

$$
X_{i}=\left(\frac{\xi_{i}-\xi_{i}^{-}}{S_{i}}\right) \quad i=1,2, \ldots k
$$

where $X_{\mathrm{i}}$ is the coded value of an input variable, $\xi_{\mathrm{i}}$ is the specific location of independent variable, $\xi_{i}^{-}$is the center point and is the scale factor i.e. the difference between $\xi_{\mathrm{i}}$ and $\xi_{\mathrm{i}}^{-}$. The specific codes for the selected input variables were calculated by putting the values of $\xi_{\mathrm{i}}$, $\xi_{\mathrm{i}}^{-}$and $\mathrm{S}_{\mathrm{i}}$ in the generalized equation as:

$$
\begin{gathered}
X_{1}(\text { Mesh No. })=\frac{[\text { Mesh No. }(\text { meshes })-60]}{20} \\
X_{2}(\text { Radiation dose })=\frac{[\text { Radiation dose }(k G y)-50]}{25}
\end{gathered}
$$

The calculated codes and combination of coded and actual levels of input variables as per chosen by CCD are shown in Table I.

The optimum point of response variables was searched by performing sequential experimentation. A response surface polynomial quadratic model was developed to find the levels of input variables in a region of optimal response. The developed model determines the relationship of antioxidant properties of maize flour against the particle size and the dose of gamma radiations. The study was done in phases based on CCD which consists of 13 points with $\mathrm{nf}=4$, factorial points, $\mathrm{na}=4$ axial point and $n c=5$ center points.

\section{Sieving}

The flour was sieved successively through micro screens of mesh No. 40, 60 and 80 meshes to obtain required levels of particle size. The distribution of particle size was done on the basis of sieve mesh number. Particle size is inversely proportional to sieve mesh number. A gradual increase in mesh number is associated with a respective decrease in particle size. The range of particle size obtained from selected sieves was as follows (SigmaAldrich, 2011):

$\begin{array}{cc}\text { Sieve No. (meshes) } & \text { Particle size }(\mu \mathrm{m}) \\ 40 & 250-420 \\ 60 & 177-250 \\ 80 & <1-177\end{array}$

\section{Gamma irradiation of flour}

The maize flour was subjected to gamma irradiation in transparent glass bottles at selected levels of radiation dose at a dose rate of $0.26 \mathrm{kGy} / \mathrm{h}$, sample to source distance $1.5 \mathrm{~m}$ and average temperature $30{ }^{\circ} \mathrm{C}$ using ${ }^{60} \mathrm{Co}$ (32000 Curies) gamma radiation source at Pakistan Radiation Services (PARAS), Lahore, Pakistan. Cericcereus dosimeters were used to measure the absorbed dose. The gamma irradiated samples and non-irradiated flour at each level of particle size (taken as control) were 
stored at $25 \pm 5^{\circ} \mathrm{C}$ in a sterile laboratory environment to minimize the chances of microbial contamination and growth throughout the study period. The exposure of the samples to direct sunlight was prevented throughout the study period in order to minimize the chances of photooxidation of antioxidant compounds.

\section{Preparation of Extracts}

The seed flour was soaked in $75 \%$ methanol at $1: 10$ solid to the solvent ratio for $24 \mathrm{~h}$ at $25 \pm 5{ }^{\circ} \mathrm{C}$ with occasional shaking. The contents were filtered through Whatman filter paper (40), the volume of the filtrate was made up to $100 \mathrm{~mL}$ with $75 \%$ methanol and used for analysis.

\section{Antioxidant analysis}

\section{Total antioxidant activity (TAOA) by phospho- molybdenum assay}

Trolox equivalent total antioxidant activity of extracts was evaluated by Phospho-molybdenum assay described earlier (Prieto, Pineda, Aguilar, 1999). The methanolic extract $(0.1 \mathrm{~mL})$ was mixed with reagent solution ( $600 \mathrm{mM}$ sulphuric acid, $4 \mathrm{mM}$ ammonium molybdate, $0.05 \mathrm{M}$ sodium phosphate buffer). The contents were incubated at $95{ }^{\circ} \mathrm{C}$ for $90 \mathrm{~min}$, cooled to room temperature and absorbance was recorded at $695 \mathrm{~nm}$ against blank (without extract). Total antioxidant capacity was calculated as Trolox equivalent $\mathrm{g} / 100 \mathrm{~g}$ dry weight using regression equation obtained from the standard curve $\left(R^{2}=0.9897\right)$.

\section{Reducing power (RP)}

The ferric reducing antioxidant power of the samples was estimated according to the method reported earlier (Oyaizu, 1986). The methanolic extract $(2.5 \mathrm{~mL})$ was mixed with phosphate buffer solution of $\mathrm{pH} 6.6(2.5 \mathrm{~mL})$ and $1 \%$ potassium ferricyanide solution $(2.5 \mathrm{~mL})$. The mixture was incubated at $50{ }^{\circ} \mathrm{C}$ for $20 \mathrm{~min}$ followed by the addition of $10 \%$ trichloroacetic acid solution $(2.5 \mathrm{~mL})$. The mixture was centrifuged at $2000 \mathrm{rpm}$ for $10 \mathrm{~min}$. The supernatant $(5 \mathrm{~mL})$ was mixed with distilled water $(5 \mathrm{~mL})$ and $0.1 \%$ ferric chloride solution $(1 \mathrm{~mL})$ and absorbance was recorded at $700 \mathrm{~nm}$. The reducing power was expressed in terms of decrease in absorbance of the reaction mixture.

\section{Linoleic acid reduction capacity (LARC)}

The linoleic acid reduction capacity of methanolic extracts was determined by using the method described earlier (Osawa, Namiki, 1981). The methanolic extract
$(2 \mathrm{~mL})$ was mixed with $2.5 \%$ ethanolic solution of linoleic acid $(2 \mathrm{~mL}), 0.05 \mathrm{M}$ sodium phosphate buffer of $\mathrm{pH} 7.0$ $(2 \mathrm{~mL})$ and distilled water $(2 \mathrm{~mL})$. The reaction mixture was incubated at $40{ }^{\circ} \mathrm{C}$ for $24 \mathrm{~h}$. An aliquot $(0.1 \mathrm{~mL})$ from above mixture was mixed with $75 \%$ methanol $(9.7$ $\mathrm{mL}), 20 \mathrm{mM} \mathrm{FeCl}_{2}$ solution $(0.1 \mathrm{~mL})$ and $30 \%$ ammonium thiocyanate solution $(0.1 \mathrm{~mL})$ and allowed to stand for $3 \mathrm{~min}$. The absorbance was recorded at $500 \mathrm{~nm}$ and LARC was calculated in terms of percent inhibition of lipid peroxidation in linoleic acid emulsion by following equation:

$$
\operatorname{LARC}(\%)=\left[1-\left(\frac{A_{s}}{A_{c}}\right)\right] \times 100
$$

where $A_{c}$ is the absorbance of control (solution without extracts or standards) and $A_{s}$ is the absorbance in the presence of sample or standard.

\section{Iron chelating Ability (ICA)}

Iron chelating ability of extracts was estimated by reported method (Puntel, Nogueira, Rocha, 2005) with some modifications. Methanolic extract $(1 \mathrm{~mL})$ was mixed with $0.1 \mathrm{M}$ hydrochloric acid solution $(1.6 \mathrm{~mL})$, saturated sodium chloride solution $(2.18 \mathrm{~mL})$ and $2 \mathrm{mM}$ ferrous sulfate solution $(1.5 \mathrm{~mL})$ successively. The mixture was allowed to stand at $25 \pm 2{ }^{\circ} \mathbf{C}$ for 5 min followed by the addition of $0.25 \%$ 1,10-phenanthroline solution ( $1.3 \mathrm{~mL})$. The absorbance of the reaction mixture was recorded at 510 $\mathrm{nm}$ after $5 \mathrm{~min}$. The iron chelating ability was calculated in terms of their $\mathrm{EC}_{50}$ (effective concentration required for $50 \%$ chelation) values for iron using regression equation obtained from the linear curve $\left(R^{2}=0.9734\right)$ of series of different dilutions of methanolic extracts.

\section{Statistical Analysis}

The results were expressed as means of three parallel replicates. The prediction of optimum levels of response variable as a function of input variables was achieved by creating polynomial quadratic response surface models. The generalized polynomial model for predicting the variation in response variables is given below:

$$
Y_{i}=\mathrm{B}_{0}+\mathrm{B}_{1} X_{1}+\mathrm{B}_{2} X_{2}+\mathrm{B}_{12} X_{1} X_{2}+\mathrm{B}_{11} X_{1}^{2}+\mathrm{B}_{22} X_{2}^{2}
$$

where $Y_{i}$ is the predicted response, $\beta_{o}$ is a constant, $\beta_{1}$ and $\beta_{2}$ are the regression coefficients for the main variable effects, $\beta_{11}$ and $\beta_{22}$ are quadratic effects and $\beta_{12}$ is interaction effect of independent variables. 
The significance of estimated regression coefficient for each response was assessed by lack of fit test ( $F$-value) at a probability $(p)$ of 0.05 . The coefficient of determination $\left(R^{2}\right)$ and the adjusted coefficient of determination $\left(R_{a d j}^{2}\right)$ were also determined to check the adequacy of the response surface models and to measure the fairness of fit of regression equation respectively. The precision and reliability of experiments were checked by determining the coefficient of variation $(C V)$. A low value of $C V$ suggests a better precision and reliability of the experiments. A ratio greater than 4 indicates an adequate signal. The statistical software, Design Expert 9.0 (Stat-Ease, Inc.) was used for the development of experimental design, data analysis and optimization procedure.

For graphical optimization of particle size and dose of gamma radiation, the three-dimensional plots were constructed between response and independent variables. The adequacy of the response surface models was verified by plotting the experimental values versus those predicted by the final reduced models. The optimum levels of input variables at which the desired goals of responses may be achieved were found by numerical optimization of data at maximum desirability.

\section{RESULTS AND DISCUSSION}

Maize flour is a source of carbohydrates and protein. It also contains some nonnutritional components such as phenolic compounds, flavonoids, tannins, anthocyanins and cardiac glycosides generally known as phytochemicals (Nawaz, Shad, Batool, 2013). These phytochemicals have been reported to possess antioxidant properties. Antioxidants are the natural or synthetic compounds which are generally known to prevent the oxidation of endogenous and exogenous biomolecules due to their hydrogen donating ability. The antioxidants show their action by trapping endogenous free radicals produced as a result of different metabolic processes and protect the lipids, proteins and nucleic acids from the oxidative damage (Kabel, 2014).

The experimental values of antioxidant activities of non-irradiated and gamma irradiated flour at different levels of particle size as per chosen by the experimental design are presented in Table I. Trolox equivalent TAOA $(\mathrm{g} / 100 \mathrm{~g} \mathrm{dw}), \mathrm{RP}$ (absorbance at $700 \mathrm{~nm}$ ) and LARC (\%) ranged from 1.50 to $3.48,0.215$ to 0.354 and 25.75 to 68.88 respectively. Iron chelating ability was determined in terms of $\mathrm{IC}_{50}$ which ranged from 0.304 to $0.350 \mathrm{mg} /$ $\mathrm{mL}$ of extract. Relatively low value of $\mathrm{IC}_{50}$ shows good chelating ability. Statistically significant difference $(p<0.05)$ in antioxidant activities was observed among non-irradiated maize flours of different particle sizes.

\section{Response surface analysis and optimization of results}

The cumulative effect of particle size and gamma radiation on antioxidant activities of maize flour was optimized by response surface methodology. The prediction of an optimum level of each of the independent variables was carried out by using central composite design (CCD).

The following polynomial regression equations were yielded by RSM in order to show an empirical relationship between the process variables and antioxidant activities of maize flour:

TAOA $(\mathrm{g} / 100 \mathrm{~g} \mathrm{dw})=-2.1236+0.116 \mathrm{X}_{1}+0.05393 \mathrm{X}_{2}+$ $2.25 \mathrm{E}^{-004} \mathrm{X}_{1} \mathrm{X}_{2}-8.629 \mathrm{E}^{-004} \mathrm{X}_{1}^{2}-7.523 \mathrm{E}^{-004} \mathrm{X}_{2}^{2}$

$\mathrm{ICA}\left(\mathrm{IC}_{50} \mathrm{mg} / \mathrm{mL}\right)=0.881-0.0173 \mathrm{E}^{-004} \mathrm{X}_{1}-5.00 \mathrm{E}^{-003} \mathrm{X}_{2}$ $-3.45 \mathrm{E}^{-005} \mathrm{X}_{1} \mathrm{X}_{2}+1.489 \mathrm{E}^{-004} \mathrm{X}_{1}^{2}+8.091 \mathrm{E}^{-005} \mathrm{X}_{2}^{2}$

$\mathrm{RP}($ Abs. at $700 \mathrm{~nm})=0.691-0.012 \mathrm{X}_{1}-4.62 \mathrm{E}^{-003} \mathrm{X}_{2}+$ $2.00 \mathrm{E}^{-005} \mathrm{X}_{1} \mathrm{X}_{2}+1.07 \mathrm{E}^{-004} \mathrm{X}_{1}{ }^{2}+2.055 \mathrm{E}^{-005} \mathrm{X}_{2}^{2}$

$\operatorname{LARC}(\%)=188.00-4.00 \mathrm{X}_{1}-1.558 \mathrm{X}_{2}+2.600 \mathrm{E}^{-003} \mathrm{X}_{1} \mathrm{X}_{2}$ $+0.0358 \mathrm{X}_{1}^{2}+9.082 \mathrm{E}^{-003} \mathrm{X}_{2}^{2}$

These equations include the coefficient for intercept, main (linear) effects, interaction terms and quadratic effects. The influence of each factor on the response is shown by the sign and magnitude of the main effect. The main, quadratic and interaction effects of particle size and radiation dose on TETAOA, ICA, RP and LARC of maize flour as obtained by analysis of variance (ANOVA) are given in Table IIa, IIb, IIc and IId respectively. The significance and adequacy of the response surface model were measured in terms of $F$-value (lack of fit) and $p$-value (probability) at $5 \%$ significance level $(p \leq 0.05)$. The $F$-value is a measure of the failure of a model to fit the data in experimental domain particularly for reduced points in a randomized experiment. The corresponding variables with relatively larger $F$-values $(F>3.69)$ and smaller $p$-values $(p<0.05)$ were considered more significant. The measurement of $F$-value and $p$-values indicated the significant linear negative effect of both variables on each of the studied parameters except TETAOA. Interaction effects were found to be nonsignificant on each of the studied parameters. The quadratic effect of particle size was found to be significant on each parameter while that of radiation dose was found to be significant on TETAOA and ICA. It is clear from RSM results that antioxidant activity of maize flour is significantly decreased in response to a 
TABLE I - The experimental values of antioxidant activity of maize flour at random levels of experimental conditions as per chosen by central composite design

\begin{tabular}{|c|c|c|c|c|c|c|c|c|}
\hline \multirow[b]{2}{*}{ Exp. Runs } & \multicolumn{2}{|c|}{ Coded levels of variables } & \multicolumn{2}{|c|}{ Actual levels of variables } & \multicolumn{4}{|c|}{ Antioxidant activity } \\
\hline & $\mathbf{X}_{1}$ & $\mathbf{X}_{2}$ & $\begin{array}{c}\xi_{1} \\
\text { Particle size } \\
\text { (Meshes) }\end{array}$ & $\begin{array}{c}\xi_{2} \\
\text { Radiation } \\
\text { dose (kGy) }\end{array}$ & $\begin{array}{c}\text { TETAOA } \\
(\mathrm{g} / 100 \mathrm{~g} \mathrm{dw})\end{array}$ & $\begin{array}{c}\mathrm{ICA} \\
\left(\mathrm{IC}{ }_{50}\right. \\
\mathrm{mg} / \mathrm{mL})\end{array}$ & $\begin{array}{c}\text { RP } \\
\text { (Abs. at } \\
700 \mathrm{~nm})\end{array}$ & LARC (\%) \\
\hline \multicolumn{9}{|c|}{ Non irradiated flour } \\
\hline & & & 40 & & 2.70 & 0.250 & 0.323 & 45.76 \\
\hline & & & 60 & & 3.25 & 0.246 & 0.349 & 56.28 \\
\hline & & & 80 & & 3.48 & 0.215 & 0.360 & 68.88 \\
\hline \multicolumn{9}{|c|}{ Gamma irradiated flour } \\
\hline $1^{*}$ & -1 & -1 & 40 & 25 & 2.28 & 0.296 & 0.310 & 54.34 \\
\hline 2 & 0 & 0 & 60 & 50 & 3.20 & 0.231 & 0.225 & 27.55 \\
\hline $3^{*}$ & 1 & -1 & 80 & 25 & 3.03 & 0.295 & 0.340 & 65.87 \\
\hline 4 & -1 & 1 & 40 & 75 & 1.50 & 0.420 & 0.210 & 25.75 \\
\hline 5 & 0 & -1 & 60 & 25 & 2.86 & 0.292 & 0.270 & 50.26 \\
\hline 6 & 1 & 1 & 80 & 75 & 2.70 & 0.354 & 0.280 & 42.48 \\
\hline 7 & -1 & 0 & 40 & 50 & 2.50 & 0.321 & 0.235 & 36.73 \\
\hline 8 & 0 & 0 & 60 & 50 & 3.20 & 0.230 & 0.225 & 27.55 \\
\hline 9 & 1 & 0 & 80 & 50 & 3.41 & 0.256 & 0.320 & 58.98 \\
\hline $10^{*}$ & 0 & 0 & 60 & 50 & 3.20 & 0.231 & 0.225 & 27.55 \\
\hline $11^{*}$ & 0 & 0 & 60 & 50 & 3.20 & 0.231 & 0.225 & 27.55 \\
\hline $12^{*}$ & 0 & 0 & 60 & 50 & 3.20 & 0.231 & 0.225 & 27.55 \\
\hline 13 & 0 & 1 & 60 & 75 & 2.80 & 0.266 & 0.225 & 28.18 \\
\hline \multicolumn{3}{|c|}{ Input variable } & \multicolumn{3}{|c|}{ Actual levels } & \multicolumn{3}{|c|}{ Respective coded level } \\
\hline \multicolumn{3}{|c|}{ Mesh No.(meshes) } & \multicolumn{3}{|c|}{$40,60,80$} & \multicolumn{3}{|c|}{$-1,0,1$} \\
\hline \multicolumn{3}{|c|}{ Radiation dose (kGy) } & \multicolumn{3}{|c|}{$25,50,75$} & \multicolumn{3}{|c|}{$-1,0,1$} \\
\hline
\end{tabular}

${ }^{*}$ Center points, ${ }^{* *} \mathrm{dw}$ : dry weight

decrease in mesh number (increase in particle size) and increase in gamma radiation doses.

The correlation coefficient $\left(R^{2}\right)$ measures the variability of the model in the observed response values. A value of $R^{2}$ closer to unity gives a better prediction of the response and high significance of the model. The values of $R^{2}(0.8819-0.9653)$ indicated that $88-96 \%$ of the variability in antioxidant properties of maize flour could be explained by the suggested model. The values of adjusted $R^{2}(0.7975-$ $0.9406)$ for these responses also advocate the significance of the model. Relatively low values (4.45-11.34) of the coefficient of variation $(\mathrm{CV})$ and high value of adequate precision (9.937-20.74) suggest a better precision and reliability of the experiments.

Three-dimensional (3D) response surface plots were drawn to show the main and interaction effects of particle size and gamma radiation dose on antioxidant activity of maize flour (Figure 1). To test the applicability of the model, the predicted values of antioxidant activities were calculated from the polynomial regression equations and plotted against the experimental values (Figure 2A-D). A good agreement between the experimental and predicted values of responses was observed with high values of coefficients of determination $\left(R^{2}=0.8819-0.9653\right)$. The higher values of $R^{2}$ prove the applicability of proposed model with greater accuracy to study the effect of particle size and radiation dose on the antioxidant properties of maize flour.

The selection criteria and results for numerical optimization of particle size and radiation dose to achieve the desirable values of antioxidant ability are presented in Table III. The optimum level of particle size in terms 
TABLE IIA - Analysis of variance (ANOVA) from the final reduced models for Trolox equivalent total antioxidant activity of gamma irradiated maize flour

\begin{tabular}{lccccc}
\hline Source & Sum of Squares & df & Mean Square & F Value & p-Value \\
\hline Model & 2311.93 & 5 & 462.39 & 24.27 & 0.0003 \\
A-Mesh No. (meshes) & 425.21 & 1 & 425.21 & 22.32 & 0.0021 \\
B-Radiation dose (kGy) & 914.15 & 1 & 914.15 & 47.98 & 0.0002 \\
AB & 6.76 & 1 & 6.76 & 0.35 & 0.5702 \\
A $^{2}$ & 565.69 & 1 & 565.69 & 29.69 & 0.0010 \\
B $^{2}$ & 89.00 & 1 & 89.00 & 4.67 & 0.0675 \\
\hline Mean & & & 2.85 & & \\
Std. Dev. & & & 0.13 & & \\
C.V. \% & & & 4.45 & & \\
R-Squared & & & 0.9653 & & \\
Adjusted R-Squared & & 0.9406 & & \\
Predicted R-Squared & & 0.6778 & & \\
Adequate Precision & & & 20.074 & & \\
\hline
\end{tabular}

$\overline{{ }^{* *}} p \leq 0.05$ indicates significant variation at $95 \%$ confidence level.

TABLE IIB - Analysis of variance (ANOVA) from the final reduced models for for iron chelating activity of gamma irradiated maize flour

\begin{tabular}{lccccc}
\hline Source & Sum of Squares & df & Mean Square & F Value & p-Value \\
\hline Model & 0.035 & 5 & $7.054 \mathrm{E}-003$ & 10.45 & 0.0038 \\
A-Mesh No. (meshes) & $3.038 \mathrm{E}-003$ & 1 & $3.038 \mathrm{E}-003$ & 4.50 & 0.0716 \\
B-Radiation dose (kGy) & $3.902 \mathrm{E}-003$ & 1 & $3.902 \mathrm{E}-003$ & 5.78 & 0.0472 \\
$\mathrm{AB}$ & $1.190 \mathrm{E}-003$ & 1 & $1.190 \mathrm{E}-003$ & 1.76 & 0.2259 \\
$\mathrm{~A}^{2}$ & $9.801 \mathrm{E}-003$ & 1 & $9.801 \mathrm{E}-003$ & 14.52 & 0.0066 \\
$\mathrm{~B}^{2}$ & $7.063 \mathrm{E}-003$ & 1 & $7.063 \mathrm{E}-003$ & 10.46 & 0.0144 \\
\hline Mean & & & 0.026 & & \\
Std. Dev. & & & 0.28 & & \\
C.V. \% & & & 9.27 & & \\
R-Squared & & & 0.8819 & & \\
Adjusted R-Squared & & & -0.7975 & & \\
Predicted R-Squared & & & 9.937 & & \\
Adequate Precision & & & & &
\end{tabular}

${ }^{* *} p \leq 0.05$ indicates significant variation at $95 \%$ confidence level.

of sieve mesh No. was found to be 70.622 for TAOA, 80 for RP and LARC and 57 for ICA. The optimum level of radiation dose at which antioxidant properties were affected to a minimum value was found to be $25 \mathrm{kGy}$ for each parameter.

\section{CONCLUSION}

The present study shows an inverse correlation between particle size and gamma radiation dose and antioxidant properties. It is concluded that smaller the 
TABLE IIC - Analysis of variance (ANOVA) from the final reduced models for reducing power of gamma irradiated maize flour

\begin{tabular}{lccccc}
\hline Source & Sum of Squares & df & Mean Square & F Value & p-Value \\
\hline Model & 0.022 & 5 & $4.445 \mathrm{E}-003$ & 34.86 & $<0.0001$ \\
A-Mesh No. (meshes) & $7.004 \mathrm{E}-003$ & 1 & $7.004 \mathrm{E}-003$ & 54.93 & 0.0001 \\
B-Radiation dose (kGy) & $7.004 \mathrm{E}-003$ & 1 & $7.004 \mathrm{E}-003$ & 54.93 & 0.0001 \\
AB & $4.000 \mathrm{E}-004$ & 1 & $4.000 \mathrm{E}-004$ & 3.14 & 0.1198 \\
$\mathrm{~A}^{2}$ & $5.070 \mathrm{E}-003$ & 1 & $5.070 \mathrm{E}-003$ & 39.76 & 0.0004 \\
$\mathrm{~B}^{2}$ & $4.557 \mathrm{E}-004$ & 1 & $4.557 \mathrm{E}-004$ & 3.57 & 0.1006 \\
\hline Mean & & & 0.011 & & \\
Std. Dev. & & & 0.25 & & \\
C.V. \% & & & 4.46 & & \\
R-Squared & & & 0.9614 & & \\
Adjusted R-Squared & & & 0.9338 & & \\
Predicted R-Squared & & & & & \\
Adequate Precision & & & & & \\
\hline
\end{tabular}

${ }^{* *} p \leq 0.05$ indicates significant variation at $95 \%$ confidence level.

TABLE IID - Analysis of variance (ANOVA) from the final reduced models for linoleic acid reduction capacity of irradiated maize flour

\begin{tabular}{lccccc}
\hline Source & Sum of Squares & df & Mean Square & F Value & p-Value \\
\hline Model & 2311.93 & 5 & 462.39 & 24.27 & 0.0003 \\
A-Mesh No. (meshes) & 425.21 & 1 & 425.21 & 22.32 & 0.0021 \\
B-Radiation dose (kGy) & 914.15 & 1 & 914.15 & 47.98 & 0.0002 \\
AB & 6.76 & 1 & 6.76 & 0.35 & 0.5702 \\
$\mathrm{~A}^{2}$ & 565.69 & 1 & 565.69 & 29.69 & 0.0010 \\
$\mathrm{~B}^{2}$ & 89.00 & 1 & 89.00 & 4.67 & 0.0675 \\
\hline Mean & & & 4.36 & & \\
Std. Dev. & & & 38.49 & & \\
C.V. \% & & & 0.9455 & & \\
R-Squared & & & 0.9065 & & \\
Adjusted R-Squared & & 0.5910 & & \\
Predicted R-Squared & & & 15.551 & & \\
Adequate Precision & & & & &
\end{tabular}

${ }^{* *} p \leq 0.05$ indicates significant variation at $95 \%$ confidence level.

particle size of flour and lower the radiation dose, the lower would be the loss of antioxidant activity. The low values of antioxidant properties of flour with large particle size may be attributed to poor extraction of bound antioxidant compounds due to small surface area. The decrease in antioxidant properties of flour treated at high radiation dose may be due to gamma rays induced oxidative degradation of antioxidant compounds. The present results suggest that sieving of flour through a sieve with higher mesh number and treatment with high-dose gamma radiation decrease 

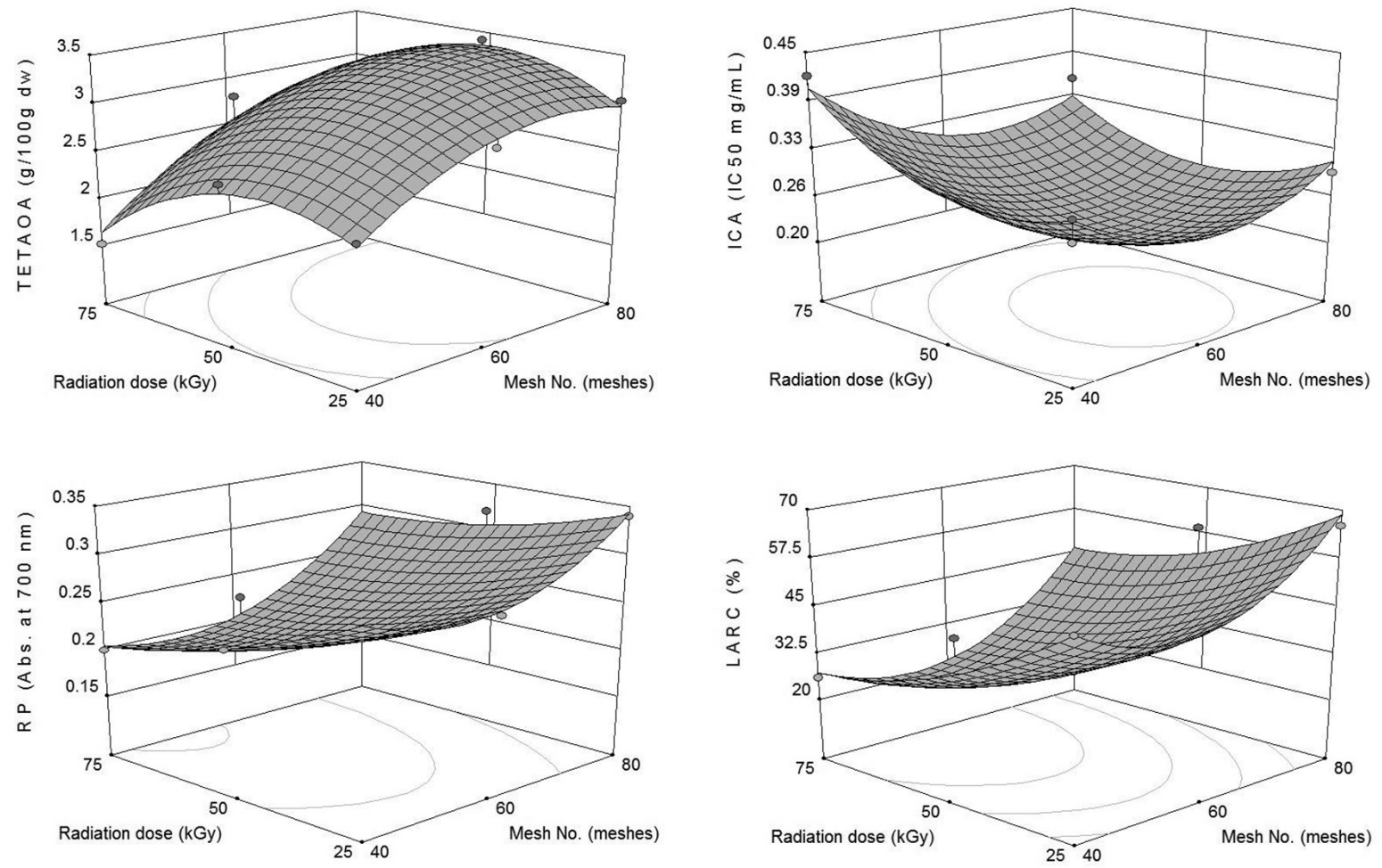

FIGURE 1 - 3D response surface plots of antioxidant properties of maize flour at various levels of particle size and radiation dose.
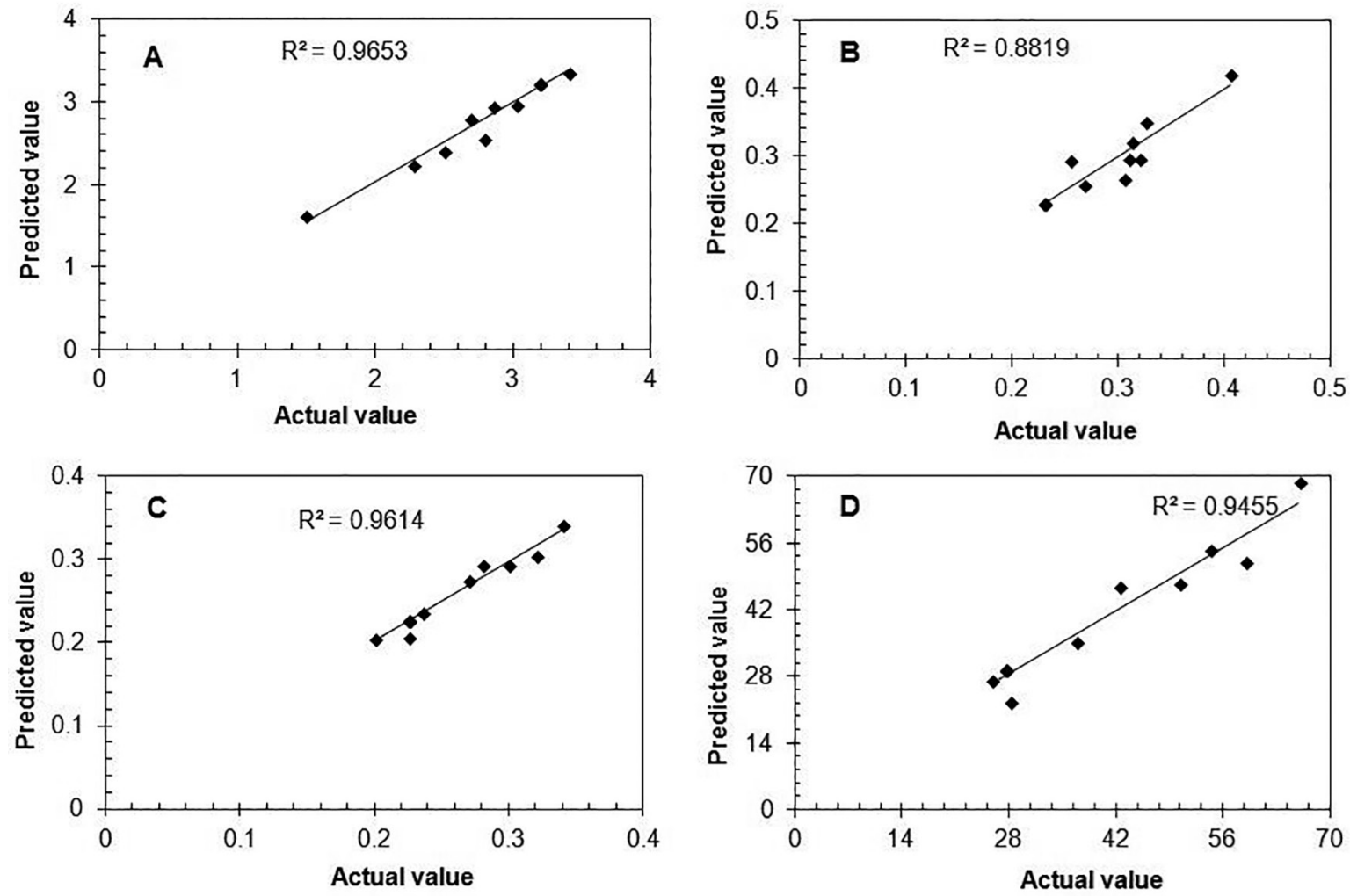

FIGURE 2A-D - Agreement between experimental values and predicted values of antioxidant properties of maize flour. A: Total antioxidant activity, B: Iron chelation activity, C: Reducing power, D: Linoleic acid reduction capacity. 
TABLE III - Optimum levels of input variables to achieve the desired goals of response variables with maximum desirability

\begin{tabular}{lccccccc}
\hline \multirow{2}{*}{ Variables } & \multirow{2}{*}{ Goal } & \multirow{2}{*}{ Lower limit } & \multirow{2}{*}{ Upper limit } & \multicolumn{3}{c}{ Optimum level } & Desirability \\
\cline { 5 - 6 } & & & & $\boldsymbol{X}_{\boldsymbol{I}}$ & $\boldsymbol{X}_{2}$ & $\boldsymbol{Y}$ & \\
\hline Mesh No (meshes) & in range & 40.00 & 80.00 & & & & \\
Radiation dose $(\mathrm{kGy})$ & in range & 25.00 & 75.00 & & & & \\
TAOA $(\mathrm{TE}$ g/100g dw) & maximize & 1.5 & 3.41 & 70.622 & 25.429 & 3.063 & 0.901 \\
$\mathrm{ICA}\left(\mathrm{IC}_{50} \mathrm{mg} / \mathrm{mL}\right)$ & minimize & 0.23 & 0.42 & 57.000 & 25.000 & 0.257 & 0.927 \\
$\mathrm{RP}(\mathrm{Abs}$. at $700 \mathrm{~nm})$ & maximize & 0.2 & 0.34 & 80.000 & 25.000 & 0.342 & 1.000 \\
LARC $(\%)$ & maximize & 25.75 & 65.87 & 80.000 & 25.000 & 68.712 & 1.000 \\
\hline
\end{tabular}

the extraction efficiency and bioavailability of antioxidant compounds from maize flour.

\section{ACKNOWLEDGMENTS}

The authors are grateful to Pakistan Radiation Services (PARAS), Lahore, Pakistan for providing the facility of gamma radiation source.

\section{REFERENCES}

ABDELWHAB, N.M.; NOUR, A.M.; FAGEER, A.S.M. The nutritive and functional properties of dry bean (Phaseolus vulgaris) as affected by gamma irradiation. Pak. J. Nutr., v.8, n.11, p.1739-1742, 2009

GANI, A.; GAZANFAR, T.; JAN, R.; WANI, S.M.; MASOODI, F.A. Effect of gamma irradiation on the physicochemical and morphological properties of starch extracted from lotus stem harvested from Dal lake of Jammu and Kashmir, India. J. Saudi Soc. Agric. Sci., v.12, 109-115, 2013.

GOUFO, P.; TRINDADE, H. Rice antioxidants: phenolic acids, flavonoids, anthocyanins, proanthocyanidins, tocopherols, tocotrienols, $\boldsymbol{\gamma}$-oryzanol, and phytic acid. Food Sci. Nutr., v.2, n.2, p.75-104, 2014.

HARRISON, K.; WERE, M.L. Effect of gamma irradiation on total phenolic content yield and antioxidant capacity of almond skin extracts. Food Chem., v.102, p.932-937, 2007.

HASSAN, A.B.; OSMAN, G.A.M.; RUSHDI, M.A.H.; ELTAYEB, M.M.; DIAB, E.E. Effect of gamma irradiation on the nutritional quality of maize cultivars (Zea mays) and sorghum (Sorghum bicolor) Grains.. Pak. J. Nutr., v.8, n.2, p.167-171, 2009.
HUSSEIN, S.Z.; YUSOFF, K.M.; MAKPOL, S.; YUSOF, Y.A.M. Antioxidant capacities and total phenolic contents increase with gamma irradiation in two types of malaysian honey. Molec., v.16, p.6378-6395, 2011.

KABEL, A.M. Free radicals and antioxidants: role of enzymes and nutrition. J. Nutr. Health, v.2, n.3, p.35-38, 2014.

KHAN, M.; IQUBAL, A.; JOSHI, A.; AJAI, K. Role of antioxidants in prevention of cancer: a review. Int. J. Curr. Res. Rev., v.6, n.9, p.80-88, 2014

KORTEI, N.K.; ODAMTTEN, G.T.; OBODAI, M.; APPIAH,V.; AKUAMOA, F.; ADU-BOBI, A.K.; ANNAN, S.N.Y.; ARMAH, J.N.O.; ACQUAH, S.A. Evaluating the effect of gamma radiation on the total phenolic content, flavonoids, and antioxidant activity of dried Pleurotus ostreatus ((Jacq. ex. Fr) Kummer) stored in packaging materials. $A d v$. Pharm., v.2014, p.1-8, 2014.

LOBO, V.; PATIL, A.; PHATAK, A.; CHANDRA, N. Free radicals, antioxidants and functional foods: Impact on human health. Pharmacogn. Rev., v.4, n.8, p.118-126, 2010.

MBOYA, R.; TONGOONA, P.; DERERA, J.; MUDHARA, M.; AND LANGYINTUO, A. The dietary importance of maize in Katumba ward, Rungwe district, Tanzania, and its contribution to household food security. Afr. J. Agric. Res., v.6, n.11, p.2617-2626, 2011.

MIRANDA-VILELAA, A.L.; PORTILHOA, F.A.; DE ARAUJO, A.V.; ESTEVANATOA, L.; MEZZOMOA, B.; SANTOSB, M.; LACAVAA, Z. The protective effects of nutritional antioxidant therapy on Ehrlich solid tumor bearing mice depend on the type of antioxidant therapy chosen: histology, genotoxicity and haematology evaluations. J. Nutr. Biochem., v.22, n.11, p.1091-1098, 2011. 
NAWAZ, H.; SHAD, M.A.; BATOOL, Z. Inter-varietal variation in biochemical, phytochemical and antioxidant composition of maize (Zea mays L.) grains. Food Sci. Technol. Res., v.19, n.6, p.1133-1140, 2013.

NIMSE, S. B.; PAL, D. Free radicals, natural antioxidants and their reaction mechanisms. RSC. Adv., v.5, p.27986-28006, 2015.

OSAWA, T.; NAMIKI, M. A novel type of antioxidant isolated from leaf wax of eucalyptus leaves. Agric. Biol. Chem., v.45, p.735-739, 1981.

OYAIZU, M. Studies on products of browning reaction: antioxidative activities of products of browning reaction prepared from glucosamine. Jap. J. Nutr. Diet., v.44, p.307315, 1986.

PRIETO, M.; PINEDA, M.; AGUILAR. Spectrophotometric quantification of antioxidant capacity through the formation of phosphomolybdenum complex: specific application of vitamin E. Anal. Biochem., v.269, n.2, p.337-341, 1999.

PUNTEL, R.L.; NOGUEIRA, C.W.; ROCHA, J.B.T. Krebs cycle intermediates modulate thiobarbituric acid reactive species (TBARS) production in rat brain In vitro. Neurochem. Res., v.30, p.225-235, 2005.
ROUSHDI, M.; HARRAS, A.; EL-MELIGI, A.; BASSIM M. Effect of high doses of gamma rays on corn grains. Part II. Influence on some physical and chemical properties of starch and its fractions. Starch, v.35, n.1, p.15-18, 1983.

ROUSHDI, M.; HARRAS, A.; EL-MELIGI, A.; BASSIM, M. Effect of high doses of gamma rays on corn grains. I. Influence on the chemical composition of whole grains and technological process of starch and By-Product Isolation. Cereal Chem., v.58, n.2, p.110-112, 1981.

SHAHIDI, F. Antioxidant in food and food antioxidants. Nahrung, v.44, p.158-163, 2000.

SIGMA-ALDRICH. Aldrich Handbook. A catalog of fine chemicals and laboratory equipment. 2012-2014. St. Louis, Missouri: Sigma Aldrich Corporation, 2011.

SISEIN, E.A. Review article: biochemistry of free radicals and antioxidants. Sch. Acad. J. Biosci., v.2, n.2, p.110-118, 2014.

VALKO, M.; LEIBFRITZ, D.; MONCOL, J.; CRONIN, M.; MAZUR, M.; TELSER, J. Free radicals and antioxidants in normal physiological functions and human disease. Int. J. Biochem. Cell Biol., v.39, n.1, p.44-84, 2007.

Received for publication on $06^{\text {th }}$ November 2015 Accepted for publication on 22 ${ }^{\text {th }}$ September 2016 